\title{
Critical Role of Astroglial Apolipoprotein E and Liver X Receptor- $\alpha$ Expression for Microglial A $\beta$ Phagocytosis
}

\author{
Dick Terwel, ${ }^{1}$ Knut R. Steffensen, ${ }^{2}$ Philip B. Verghese, ${ }^{3}$ Markus P. Kummer, ${ }^{1}$ Jan-Åke Gustafsson, ${ }^{2}$ David M. Holtzman, ${ }^{3}$ \\ and Michael T. Heneka ${ }^{1}$ \\ ${ }^{1}$ Department of Neurology, University of Bonn, 53127 Bonn, Germany, ${ }^{2}$ Department of Biosciences and Nutrition, Karolinska Institutet, S-141 57 \\ Huddinge, Sweden, and ${ }^{3}$ Department of Neurology, Washington University School of Medicine, St. Louis, Missouri 63110
}

Liver X receptors (LXRs) regulate immune cell function and cholesterol metabolism, both factors that are critically involved in Alzheimer's disease (AD). To investigate the therapeutic potential of long-term LXR activation in amyloid- $\beta(\mathrm{A} \beta)$ peptide deposition in an AD model, 13-month-old, amyloid plaque-bearing APP23 mice were treated with the LXR agonist T0901317. Postmortem analysis demonstrated that T0901317 efficiently crossed the blood-brain barrier. Insoluble and soluble A $\beta$ levels in the treated APP 23 mice were reduced by $80 \%$ and $40 \%$, respectively, compared with untreated animals. Amyloid precursor protein (APP) processing, however, was hardly changed by the compound, suggesting that the observed effects were instead mediated by A $\beta$ disposal. Despite the profound effect on $\mathrm{A} \beta$ levels, spatial learning in the Morris water maze was only slightly improved by the treatment. ABCA1 (ATP-binding cassette transporter 1) and apolipoprotein $\mathrm{E}$ (ApoE) protein levels were increased and found to be primarily localized in astrocytes. Experiments using primary microglia demonstrated that medium derived from primary astrocytes exposed to T0901317 stimulated phagocytosis of fibrillar A $\beta$. Conditioned medium from T0901317-treated $\mathrm{ApoE}^{-1-}$ or $\mathrm{LXR} \alpha^{-1-}$ astrocytes did not increase phagocytosis of $\mathrm{A} \beta$. In APP23 mice, long-term treatment with T0901317 strongly increased the association of microglia and A $\beta$ plaques. Short-term treatment of APP/PS1 mice with T0901317 also increased this association, which was dependent on the presence of LXR $\alpha$ and was accompanied by increased ApoE lipidation. Together, these data suggest that astrocytic LXR $\alpha$ activation and subsequent release of ApoE by astrocytes is critical for the ability of microglia to remove fibrillar $\mathrm{A} \beta$ in response to treatment with T0901317.

\section{Introduction}

Ample evidence suggests a role for innate immune function and brain cholesterol metabolism in Alzheimer's disease (AD) (Mulder and Terwel, 1998; Heneka and O'Banion, 2007). Both processes happen to be under the control of liver X receptors (LXRs) (Whitney et al., 2002; Zelcer and Tontonoz, 2006). Two types of LXRs exist, $\operatorname{LXR} \alpha$ and $\operatorname{LXR} \beta$. LXR $\alpha$ is found at high levels in cholesterol-metabolizing tissues and its expression is acutely regulated (Whitney et al., 2001), while LXR $\beta$ is ubiquitously expressed (Baranowski, 2008). Both LXRs act as cholesterol sensors and are activated by hydroxylated forms of cholesterol, leading to induction of genes that encode for proteins directly responsible for cholesterol export from the cell, such as apolipoprotein E (ApoE), ATP-binding cassette transporters (ABCA1, ABCG1), and sterol regulatory element-binding protein 1c (SREBP1c) (Zelcer and Tontonoz, 2006). In humans ApoE is present as three

Received Dec. 15, 2010; revised Feb. 11, 2011; accepted Feb. 22, 2011.

Author contributions: D.T., P.B.V., D.M.H., and M.T.H. designed research; D.T., K.S., P.B.V., M.P.K., and D.M.H. performed research; K.S., M.P.K., and J.-A..G. contributed unpublished reagents/analytic tools; D.T., P.B.V., M.P.K., and M.T.H. analyzed data; D.T., M.P.K., J.-Å.G., and M.T.H. wrote the paper.

The work was supported by grants from Deutsche Forschungsgemeinschaft and the Federal Ministry of Education and Research (BMBF) to M.T.H. (KF0 177, TP4), by National Institutes of Health Grant AG13956 (to D.M.H.), and by American Health Assistance Foundation Grant 2010613 (to P.B.V.).

Correspondence should be addressed to Dr. Michael T. Heneka, Prof. of Clinical Neuroscience, Department of Neurology, University of Bonn, Sigmund Freud Strasse 25, 53127 Bonn, Germany. E-mail: michael.heneka@ukb.uni-bonn.de.

DOI:10.1523/JNEUROSCI.6546-10.2011

Copyright $\odot 2011$ the authors $\quad 0270-6474 / 11 / 317049-11 \$ 15.00 / 0$ different isoforms, ApoE2, -3, and -4. The fact that ApoE4 is the best described risk factor for sporadic AD (Roses, 2006) hints to a link between this disease and cholesterol metabolism. The control of innate immune cell function by LXRs is not directly related to cholesterol metabolism and involves interference of nuclear factor $\kappa \mathrm{B}$ signaling (Zelcer and Tontonoz, 2006).

Because of the central role played by lipid metabolism in the development of atherosclerosis (Beaven and Tontonoz, 2006), agonists for LXRs are under development for therapy in this condition and are currently being evaluated in respective clinical trials. This encourages research into the application of LXR agonists for other diseases in which lipid metabolism is implicated, including $\mathrm{AD}$. The fact that LXRs affect dual processes implicated in $\mathrm{AD}$ adds to the attraction to test these compounds in $\mathrm{AD}$.

Several studies have addressed the effect of LXR stimulation in cellular or rodent models of AD. It has been shown that the LXR agonists TO901317 and GW3965 alter amyloid- $\beta$ (A $\beta$ ) production in neuronal and non-neuronal cell cultures overexpressing amyloid precursor protein (APP) (Koldamova et al., 2003, 2005b; Kim et al., 2007).

Short-term administration of LXR agonists TO901317 and GW3965 to 5-month-old preplaque Tg2576 mice improved fear conditioning (Riddell et al., 2007; Jiang et al., 2008) and longterm treatment with TO901317 restored object recognition in plaque-bearing APPSLxPS1mut mice (Vanmierlo et al., 2009). Long-term treatment with GW3965 has been shown to reduce plaque formation by $50 \%$ in aged Tg2576 mice (Jiang et al., 
2008). Short-term treatments with TO901317 have shown small reductions of soluble A $\beta 40$ and -42 (Koldamova et al., 2005b), or A $\beta 42$ only, in hippocampus of Tg2576 mice (Riddell et al., 2007).

While these studies elucidate the dependence of LXR agonistmediated effects on different treatment protocols, ages, and disease stages, the underlying mechanism of LXR agonist protection in aged APP transgenic mice and, in particular, an effect on the removal of fibrillar $A \beta$ remain unclear. In the present study we investigated the role of LXRs in microglial removal of fibrillar $\mathrm{A} \beta$ in vitro and after chronic stimulation of LXRs by TO901317 in aged APP23 mice for 7 weeks from 13 months of age onwards.

\section{Materials and Methods}

Animal experiments. In the present study APP23 mice and littermate wild-type mice were used. In the APP23 mouse line, human APP751 carrying the Swedish double mutation (K670M/N671L) is overexpressed sevenfold over the endogenous mouse APP. The mice were generated on a C57BL/6 $\times$ DBA/2 background and were back-crossed into C57BL/6. APP23 mice were 13 months old at the beginning of the study. Deposition of A $\beta$ in APP23 mice starts at 6 months of age and continuously increases (Sturchler-Pierrat et al., 1997), and at 12 months substantial plaque deposition has been demonstrated (Kuo et al., 2001). Of relevance to our present work, Sturchler-Pierrat et al. (1997) have described A $\beta$ plaque-associated microglia already present at 12 months. Thus, at 13 months, when we initiated treatment with the LXR agonist, there was a substantial $A \beta$ plaque deposition, and microglia associated with it, present in APP23 mice. Mice were housed separately in individually ventilated cages 3 weeks in advance of the experiment, under standard conditions (at $22^{\circ} \mathrm{C}$, humidity $18 \%$ ) with free access to food and water on a reverse dark/light cycle of $12 \mathrm{~h}$ light and $12 \mathrm{~h}$ darkness. APP23 and control mice received $50 \mathrm{mg} / \mathrm{kg}$ TO901317 or vehicle daily by oral gavage for 7 weeks. The vehicle was a $0.5 \%$ methylcellulose solution and the compound was suspended by sonication. In week 5 of treatment, behavioral habituation of the mice was assessed in the open field. In weeks 6 and 7 , animals underwent spatial memory assessment using the Morris water maze. For blood and tissue collection the animals were shortly anesthetized by inhalation of isoflurane and received an injection of $50 \mu \mathrm{lof} 0.5 \mathrm{M}$ EDTA through the left heart chamber. Blood was drawn from the left heart chamber and stored at $-80^{\circ} \mathrm{C}$ until compound determination. Subsequently, mice were transcardially perfused with ice-cold PBS and brains were removed. One hemisphere of the brain was fixed in ice-cold 4\% paraformaldehyde, PBS overnight, and used for immunohistochemistry. The other hemisphere was separated into a hindbrain and a forebrain part. Brain parts were snap-frozen in liquid nitrogen and subsequently stored at $-80^{\circ} \mathrm{C}$ until further determination of insoluble and soluble $\mathrm{A} \beta$ species, other APP processing products, and compound determination.

Additionally, 13-month-old APP/PS1/LXR ${ }^{-1-}$ mice and APP/PS1/ $\mathrm{LXR}^{+/-}$littermates on a C57BL/6 background were used. Parental strains of these mice are described by Jankowsky et al. (2004) and Alberti et al. (2000). The APP/PS1/LXR ${ }^{-1-}$ and APP/PS1/LXR ${ }^{+1-}$ mice were treated with TO901317 as described above, but only for $6 \mathrm{~d}$. CSF was collected from the cisterna magna of these mice as previously described (DeMattos et al., 2002). Brain hemispheres were obtained as described for the APP23 mice and used for the immunohistochemical determination of the association of microglia with $\mathrm{A} \beta$.

Animal care and handling was performed according to the declaration of Helsinki and approved by the local ethical committees.

Determination of TO901317 levels in blood and brain tissue. The concentrations of TO901317 were determined in EDTA-treated blood and brain tissue (after homogenization in phosphate buffer, $\mathrm{pH}$ 7.2) by liquid chromatography/tandem mass spectrometry (LC/MS/MS). These analyses were performed on a TSQ mass spectrometer (ThermoFisher Scientific). The instrument was operated in the atmospheric pressure and negative electrospray ionization mode with selected reaction monitoring. Liquid chromatography was performed on a MaxRP Synergi column $(50 \times 2 \mathrm{~mm}, 2.5 \mu \mathrm{m}$ pore size; Phenomenex), with a gradient elution (varying the percentages of water, methanol, and acetonitrile, and with $1 \%$ formic acid). Samples were prepared using protein precipitation with acetonitrile. The limit of quantitation was $8 \mathrm{pmol} / \mathrm{ml}$ in blood and 24 $\mathrm{pmol} / \mathrm{g}$ tissue in brain.

Open field behavior. The open field consisted of a $61 \times 61 \times 61 \mathrm{~cm}$ Perspex box with dark walls and a white floor and was dimly illuminated. The open field was virtually divided into corridors along the walls $(10 \mathrm{~cm}$ wide; corners, $10 \times 10 \mathrm{~cm}$; and a center, $40 \times 40 \mathrm{~cm}$ ). Mice were put in the middle of the open field and tracked by a camera connected to a computer running on dedicated software (Ethovision, Noldus) for 10 min on 3 consecutive days. Vertical movements were registered, and distance, corridor, corner, and center times were determined.

Morris water maze. The Morris water maze used consisted of a 61-cmhigh plastic circular basin (diameter $1 \mathrm{~m}$ ) approximately half filled with water, with an invisible platform of $15 \times 15 \mathrm{~cm}$ just under water in the middle of one of four equal virtual segments (quadrants). A white curtain surrounded the basin. Three asymmetrically applied intra-maze cues were presented to the animals. The water was made turbid with white dispersion paint. The mice were subjected to 1 training session per day for 8 consecutive days. One training session consisted of 4 trials of $40 \mathrm{~s}$ each. Time between trials was $10 \mathrm{~s}$. The starting position in each trial was quasi-random. If a mouse did not succeed in finding the platform, it would be put onto it. The mice were tracked by a computer operating on dedicated software (Ethovision; Noldus), which registered vertical movements and calculated distance laid back, latency to the platform, time in quadrant, and quadrant entries.

Gel electrophoresis and Western blotting. Forebrains were weighed and homogenized by sonication in 10 volumes of Tris-buffered saline (TBS) with Complete Inhibitor Cocktail (Roche Diagnostics). Homogenates were run on $4-20 \%$ SDS-PAGE. C-terminal fragments were detected with rabbit antiserum APP-C8 raised against the C-terminal amino acids of APP (Schrader-Fischer and Paganetti, 1996). ABCA1 was detected with anti-ABCA1 antibody (1:200, Novus Biologicals, 100-1663), ApoE with anti-ApoE (1:1000, Novus Biologicals, 100-2040), and $\beta$-actin with anti- $\beta$-actin (1:5000, Sigma, A2228).

Nondenaturing gradient gel electrophoresis. Samples of CSF were mixed 1:1 with native sample buffer and electrophoresed on $4-20 \%$ TrisGlycine gels (Invitrogen). Proteins with known hydrated diameters were used as size standards (GE Healthcare). Proteins were transferred to a nitrocellulose membrane and probed with anti-goat ApoE antibody (Calbiochem, catalog \#178479, 1:200) and secondary horse anti-goat IgG linked HRP (Santa Cruz Biotechnology, Sc 2020, 1:2500), followed by horse anti-goat IgG linked to HRP (Vector Laboratories, 1:1000). Bands were visualized with enhanced chemiluminescence (Pierce) and imaged with Syngene G:Box.

A $\beta$ determination by sandwich immunoassay on MSD Multi-Array plate. Brain regions were weighed and homogenized by sonication in 10 volumes of TBS (20 mm Tris- $\mathrm{HCl}, \mathrm{pH}$ 7.6, $137 \mathrm{~mm}$ sodium chloride, and Complete Protease Inhibitor Cocktail; Roche Diagnostics). For determination of total $\mathrm{A} \beta 40$ and $\mathrm{A} \beta 42$, forebrain homogenates were extracted for $15 \mathrm{~min}$ at $4^{\circ} \mathrm{C}$ with $70 \%$ formic acid. The extracts were neutralized by addition of 19 volumes of $1 \mathrm{M}$ Tris-base and centrifuged for $15 \mathrm{~min}$ at $20,000 \times g$. For determination of TBS-soluble A $\beta$, forebrain homogenates were centrifuged at $100,000 \times g$ for $15 \mathrm{~min}$. For determination of Triton X-100-soluble A $\beta$, Triton X-100 was added to the forebrain homogenate (final concentration $1 \%$ ) and samples were extracted on ice for $15 \mathrm{~min}$ before centrifugation at $100,000 \times g$. Samples were mixed every 5 min. Human (6E10) A $\beta 40$ or A $\beta 42$ ultra-sensitive kits were used (Meso Scale Discovery). Triton X-100-soluble A $\beta$ was diluted to a final concentration of 1:100 with 3\% Blocker A. Triton X-100 extracts were diluted 1:100. Signals were measured on a SECTOR Imager 6000 reader (Meso Scale Discovery).

Determination of soluble APP $\alpha$ and soluble APP $\beta$ by sandwich immunoassay on MSD multiplex plate. Supernatants were diluted with $1 \%$ Triton X-100, TBS (final dilution 1:2000), loaded on an MS6000 soluble $\operatorname{APP} \alpha(\operatorname{sAPP} \alpha) / \operatorname{sAPP} \beta$ multiplex plate (Meso Scale Discovery), and further processed as described for $A \beta$.

Detection of $A \beta$ aggregation. FAM-A $\beta 1-42$ (Peptide Specialty Laboratories) was solubilized as previously described (Teplow, 2006). In brief, FAM-A $\beta 1$-42 was solubilized in 1,1,1-3,3,3-hexafluoroisopropanol, incubated for $10 \mathrm{~min}$, and evaporated using a SpeedVac. FAM-A $\beta 1-42$ was 
resolubilized to $221 \mu \mathrm{M}$ in $10 \mathrm{~mm} \mathrm{NaOH}$, and aggregation was started by dilution to $25 \mu \mathrm{M}$ using $50 \mathrm{~mm}$ Tris- $\mathrm{HCl}, \mathrm{pH} 7$. Samples were incubated for $18 \mathrm{~h}$ at $37^{\circ} \mathrm{C}$ and flash-frozen in liquid nitrogen. Samples were stored at $-80^{\circ} \mathrm{C}$ afterward. Aggregation state was determined by sample separation on $4-12 \%$ NuPAGE gel and Western blot using antibody 6E10 (Covance), followed by enhanced chemiluminescence detection (Millipore) using HRP-conjugates (Jackson ImmunoResearch Laboratories). Signals were analyzed using the Chemidoc XRS documentation system (Bio-Rad).

Immunohistochemistry. Free-floating $40-\mu \mathrm{m}$-thick serial sections were cut on a vibratome (Leica). Sections obtained were stored in $0.1 \% \mathrm{NaN}_{3}$, PBS in a cold room. For immunohistochemistry, sections were treated with $50 \%$ methanol for $15 \mathrm{~min}$. Then, sections were washed three times for $5 \mathrm{~min}$ in PBS and blocked in 3\% BSA, 0.1\% Triton X-100, PBS (blocking buffer) for $30 \mathrm{~min}$, followed by overnight incubation with the primary antibody in blocking buffer. Next, sections were washed three times in $0.1 \%$ Triton X-100, PBS, incubated with Alexa 488- or Alexa 594-conjugated secondary antibodies (1:500, Invitrogen) for $90 \mathrm{~min}$, and washed three times with $0.1 \%$ Triton X-100, PBS for 5 min. Finally, the sections were mounted on glasses in tap water and embedded in Mowiol solution with $0.1 \%$ 1,4-diazobicyclo[2.2.2] octan. The following primary antibodies were used with respective concentrations: rabbit polyclonal 2964 against $\mathrm{A} \beta$ (gift from Dr. Jochen Walter, University of Bonn, Bonn, Germany), rabbit polyclonal anti-ABCA1 (1:200, Novus Biologicals), goat polyclonal anti-ApoE (1:200, M-20, sc-6384, Santa Cruz Biotechnology), rabbit polyclonal anti-ApoE (1:200, ab20874, Abcam), rabbit polyclonal anti-GFAP (1:1000, Dako), rat monoclonal anti-mouse CD11b (1:200, Serotec), and rabbit polyclonal anti-Iba1 (1:500, Wako, Osaka, Japan). Fluorescence microscopy was performed using an Olympus BX61 microscope, and images were processed in Cell-P (Olympus).

Primary microglial cell culture. Primary microglial cell cultures were prepared as previously described in detail (Giulian and Baker, 1986). Briefly, mixed glial cultures were prepared from newborn mice and cultured in DMEM supplemented with $10 \% \mathrm{FCS}$ and $100 \mathrm{U} \cdot \mathrm{ml}^{-1}$ penicillin/streptomycin. Microglial cells were used after 10-14 d of primary cultivation. They were harvested by shake-off, and replated and allowed to attach to the substrate for $30 \mathrm{~min}$. Attached cells were extensively washed with culture medium and kept in culture for 1-2 $\mathrm{d}$ before being used. For the experiments, wild-type, ApoE ${ }^{-1-}$ (Plump et al., 1992), $\operatorname{LXR} \alpha^{-1-}, \operatorname{LXR} \beta^{-1-}$, and $\operatorname{LXR} \alpha^{-1-} / \beta^{-1-}$ (Alberti et al., 2000) on a C57BL/6 background were used.

Phagocytosis of FAM-labeled A 1-42 by microglial cells. Microglial phagocytosis of FAM-labeled A $\beta 1-42$ (FAM-A $\beta$ ) (AnaSpec) was measured by plate-based assay as previously described (Floden and Combs, 2006). In brief, cells were plated at a density of 50,000 per well. Cells were incubated with $500 \mathrm{~nm} \mathrm{~A} \beta$ for up to $4 \mathrm{~h}$, starting $1 \mathrm{~h}$ after plating. Finally, the $\mathrm{A} \beta$-containing medium was removed and extracellular $\mathrm{A} \beta$ was quenched with $100 \mu \mathrm{l}$ of $0.2 \%$ trypan blue in PBS, pH 4.4, for 1 min. After aspiration, fluorescence was measured at $485 \mathrm{~nm}$ excitation/ $535 \mathrm{~nm}$ emission using a SpectrafluorPlus reader (Tecan). To be able to normalize for cell numbers, cells were incubated with $100 \mu \mathrm{l}$ of $50 \mu \mathrm{g} / \mathrm{ml}$ Hoechst 33342 in PBS for $30 \mathrm{~min}$ and fluorescence was measured at 360 $\mathrm{nm}$ excitation/465 nm emission. Additionally, the occurrence of microglial $\mathrm{A} \beta$ phagocytosis was verified by confocal laser scanning microscopy. Cells were fixed with $4 \%$ formaldehyde for $10 \mathrm{~min}$ and immunostained using rat anti-mouse monoclonal antibody MCA711 for CD11b (Serotec), and lysosomes were stained using LysoTracker Red (Invitrogen). Confocal laser scanning microscopy was performed using an LSM 510 (Carl Zeiss). To validate the presence of aggregated $A \beta$ within microglia, cells were incubated with aggregated $A \beta 1-42$ overnight and stained with Thioflavin S. Fluorescence microscopy was performed using an Olympus BX61.

Determination of plaque-associated microglia. Double-immunofluorescent staining for $\mathrm{CD} 1 \mathrm{lb}$ and $\mathrm{A} \beta$ was performed using the above-described antibodies. Fields of plaques were randomly selected in the cortex. Images were made in Cell-P with automatic illumination. The area of $\mathrm{CD} 11 \mathrm{~b}$ overlaying plaques was determined with the Colocalization Finder plugin in NIH ImageJ 1.44 and corrected for total plaque area determined with the subroutine Particle Analysis after background sub- traction equal for all images and binarization. Only plaques with a diameter smaller than $30 \mu \mathrm{m}$ were included in the analysis. Per-animal coverage of $50-200$ plaques by microglia was determined. Animal number per group was 7 .

Statistical analysis. For statistical analysis, GraphPad Prism or SPSS was used. ELISA, Western blot data, or image analysis data were analyzed where appropriate by Student's $t$ test or two-way ANOVA followed by Student's $t$ tests if indicated. Behavioral data on learning in the Morris water maze were analyzed by three-way ANOVA, with transgene and treatment as the independent between-subject variables and day as within-subject variable, and distance or latency as the dependent variables. Integrated responses (area under the curve) were also analyzed for the same between-subject and dependent variables. Probe trial data were analyzed by three-way ANOVA with place (quadrant 1-4) as withinsubject variable, transgene and treatment as between-subject variables, and time as dependent variable. Probe trial data were further analyzed with repeated-measures ANOVA and Tukey's post hoc test. Data on open field behavior were analyzed by three-way ANOVA with transgene and treatment as between-subject dependent variables, day as withinsubject dependent variable, and time in corridor or center and distance laid back as dependent variables. Fluorescence measurements of uptake of labeled $A \beta$ were analyzed by one-way ANOVA followed by Tukey's post hoc tests.

\section{Results \\ Pharmacological treatment of APP23 mice with the LXR agonist TO901317}

To test whether LXR activation by the pharmacological agonist TO901317 affects the deposition of A $\beta$, 13-month-old APP23 mice were treated for 7 weeks with TO901317 (50 mg/kg) by daily oral gavage. To determine the penetration of TO901317 into the brain, the compound concentrations in brain tissue and blood were assessed at $4 \mathrm{~h}$ after the last dosing by LC/MS/MS. Treatment with TO901317 for 7 weeks resulted in hind- and forebrain concentrations that were substantially higher (approximately threefold) than those found in the peripheral blood in both APP23 mice and wild-type controls (Fig. 1A). Concentrations of the compound in the brain reached values of $\sim 5 \mathrm{nmol} / \mathrm{g}$ fresh weight, while those in the blood were $\sim 2 \mathrm{nmol} / \mathrm{ml}$. Assessment of total body weight over the entire observation period did not reveal any differences in response to drug treatment (Fig. 1B), which indicates that the drug was well tolerated. While serial inspection of livers of TO901317-treated and untreated mice revealed a tendency toward liver enlargement in response to treatment, it seems important to note that this phenomenon did not affect specific measures of animal well-being including ambulation, grooming, skin condition, open field behavior, or weight (see below). Notably, APP23 mice had a somewhat lower body weight compared with controls (two-way ANOVA, $p<0.001$ ), in accordance with their reported hypermetabolic condition (Vloeberghs et al., 2008). The factor treatment did not affect open field behavior (three-way ANOVAs, $p$ values $>0.05$ ). Open field behavior, assessed in the fifth week of treatment, was not different between APP23 and wild-type mice, except for a slightly higher activity of the transgenic mice on the first day in the open field (interaction day $X$ transgene in the threeway ANOVA and one-way ANOVA for the factor transgene on day $1, p$ values $<0.05$ ) (Fig. $1 C$ ). The effect of day was highly significant for all measures (three-way ANOVA, $p$ values $<$ 0.001 ), which means that the animals habituated to the open field.

\section{Inverse effects of TO901317 on $\mathrm{A} \beta, \mathrm{ApoE}$, and $\mathrm{ABCA1}$}

Determination of forebrain $\mathrm{A} \beta$ levels revealed a decrease by $40 \%$ and $80 \%$ of both soluble and insoluble $A \beta 1-40$ and $A \beta 1-42$ levels, 
respectively, in response to TO901317 treatment (Fig. 2A,B). Analysis of APP processing in TO901317- and vehicletreated mice revealed a slight but significant reduction of APP and soluble APP $\alpha$. Soluble APP $\beta$, C99, and C83 were not statistically different between groups (Fig. 2C). Additionally, TO901317 treatment did not alter the concentration of murine $A \beta$ in wild-type mice (Fig. 2D). Immunohistochemical analysis with an antibody directed against fibrillar $\mathrm{A} \beta$ confirmed the $\mathrm{A} \beta$-lowering effects of oral TO901317 treatment in aged APP23 mice (Fig. 2E). Quantification of Thioflavin S-stained $A \beta$ in brain sections of TO901317-treated APP23 mice revealed a strong reduction compared with nontreated APP23 mice (Fig. 2F). Collectively, these data suggest that the reduction of $\mathrm{A} \beta$ by TO901317 was not mediated by modulation of the APP processing pathway.

Treatment with TO901317 increased concentrations of ABCA1 and ApoE in APP23 and control mice (Fig. 3A-C). To investigate which brain cells are most likely to respond to TO901317, the distribution of two proteins of which the genes are targets for LXR, notably ABCA1 and ApoE, was investigated by immunohistochemistry. ABCA1 was distributed throughout the brain and could be shown to be present in astrocytes (Fig. 3D). Its presence in astrocytes could still be observed in the very fine ramifications where GFAP staining is very faint or absent (data not shown). ApoE was found in astrocytes as well (Fig. 3E), as observed by others (Fujita et al., 1999). ABCA1 and ApoE could not be found to colocalize with CD11bpositive microglia, regardless of their morphological phenotype, which here at the plaque site may reflect their response to $\mathrm{A} \beta$ (Fig. $3 D, E$ ), indicating very low levels or even the absence of these proteins in microglial cells in vivo. Immunofluorescence for ABCA1 and ApoE in astrocytes was not notably stronger in the vicinity of plaques, demonstrating that expression of these proteins is not a marker for activated astroglia. ABCA1 was present in astrocytes to the same extent in different brain areas, whereas this distribution differs greatly for GFAP. Treatment with TO901317 did not alter the cellular localization of ABCA1 and ApoE (data not shown). Immunostaining using an anti-ABCA1 antibody was absent in brain sections of $\mathrm{ABCA} 1^{-/-}$mice (Fig. $3 D$ ).

\section{Spatial learning of TO901317-treated APP23 transgenics}

Spatial learning was assessed in the Morris water maze in the sixth to seventh week of treatment. A highly significant betweensubject effect for the factor strain was observed on the dependent variables distance and latency $(p<0.001)$, indicating a spatial memory deficit in the APP23 mice compared with controls (Fig. $4 A$ ). In addition, the effect of the within-subject factor day was highly significant ( $p$ values $<0.01$ ), indicating a learning effect. An effect for the factor treatment was not observed on these variables. In conclusion, APP23 mice exhibited a clear spatial memory deficit in the Morris water maze test compared with wild-type littermates.

Data were further analyzed with respect to overall performance (average distance and latency for days 1-8), acquisition (averages for day 1-4 of training), and consolidation (averages for day 5-8 of training). The effect of the transgene was again highly significant for performance overall, during acquisition and consolidation (Fig. $4 B, C$ ). Post hoc analysis revealed a minor worsening effect of the treatment during acquisition in the wildtype animals and a minor improvement during consolidation in the APP23 mice (Fig. 4B). Together, a beneficial effect was only detectable during the consolidation but not during the acquisition phase. Overall, the magnitude of improvement was small. 
A
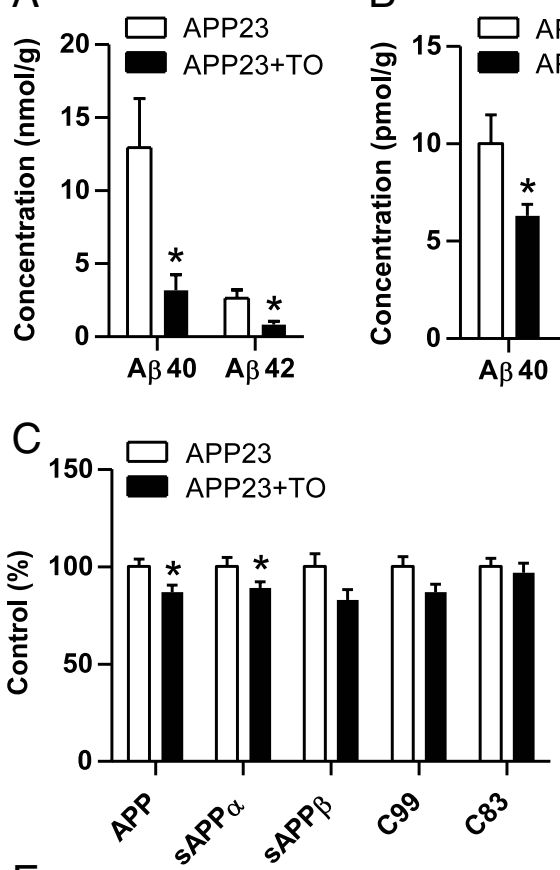

E
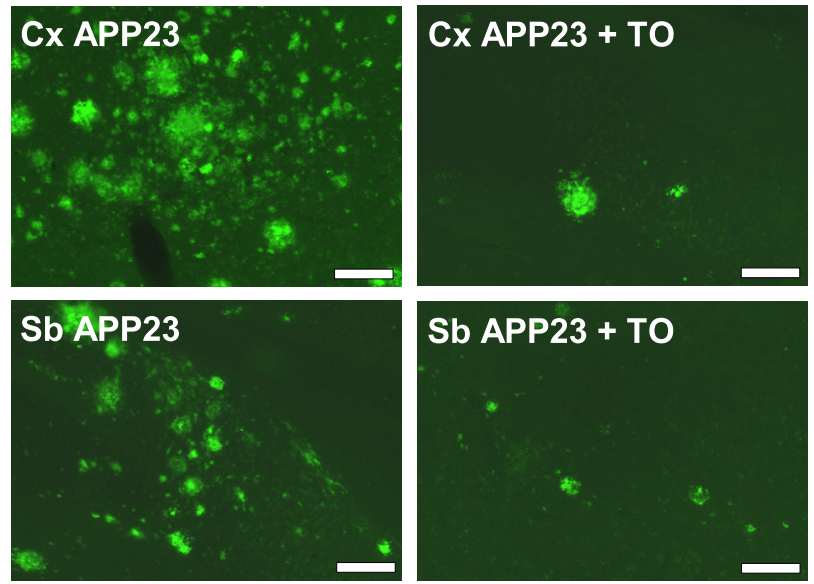

$\mathrm{F}$
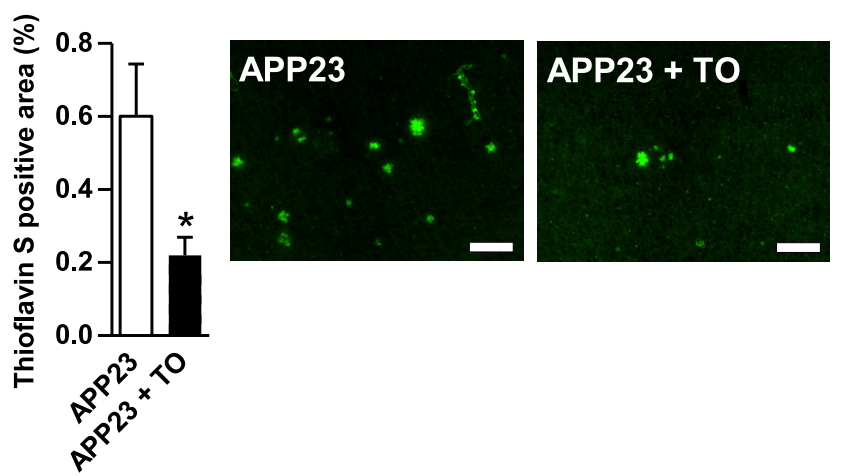

Figure 2. T0901317 reduces $A \beta$ burden in the APP23 transgenic mouse model of $A D . A, B$, Concentrations of human $A \beta 40$ and $A \beta 42$ in formic acid extracts $(\boldsymbol{A})$ or soluble fraction $(\boldsymbol{B})$ in APP23 mice, as determined by sandwich ELISA, were strongly reduced in response to T0901317 (T0; $50 \mathrm{mg} / \mathrm{kg}$ per day for 7 weeks). 6E10 was used as a capture antibody and anti-A $\beta 40$ as detection antibody. C, Sandwich immunoassay on Triton X-100 extracts or Western blot determination on brain homogenates showed a minor but significant reduction of APP and SAPP $\alpha$ upon T0901317 treatment. Capture antibodies in the sandwich immunoassay were anti-sAPP $\alpha$ and anti-SAPP $\beta$; reporter was anti-APP. For Western blot, detection of APP and the C-terminal
Three-way ANOVA of probe trial data revealed a significant effect for the factor place (quadrant) $(p<0.01)$ and an interaction between the factors place and transgene $(p<0.05)$ (Fig. $4 D)$. Further statistical analysis revealed that these effects were accounted for by a place preference of the wild-type mice (repeated measures one-way ANOVA and Tukey's post hoc test, $p<$ 0.001 ) and the absence thereof in the APP23 mice (one-way ANOVA, Tukey's post hoc test, $p>0.05$ ). The probe trial revealed that the wild-type mice used a spatial strategy, while the APP23 mice failed to do so. No treatment effects were observed on probe trial performance.

\section{Modulation of microglial A $\beta 1-42$ phagocytosis by the LXR agonist TO901317}

Phagocytosis of aged FAM-labeled $\mathrm{A} \beta 1-42$ by microglia in vitro was assayed as previously described by Floden and Combs (2006), and controlled by laser confocal microscopy and immunoprecipitation of $A \beta$ in lysates of microglial cells. Aggregation of $\mathrm{A} \beta$ upon aging was verified by Western blot analysis (Fig. $5 A$ ) and detection of Thioflavin S-positive $\mathrm{A} \beta$ in exposed microglia (Fig. $5 A$ ). Direct treatment of microglial cells for $2 \mathrm{~h}$ with the LXR agonist TO901317 did not enhance $\mathrm{A} \beta$ phagocytosis (Fig. $5 A$ ). However, when $\mathrm{A} \beta$ was presented in medium derived from astrocytes that were preexposed to increasing concentrations of the LXR agonist (TO901317, $10 \mathrm{nM}$ to $10 \mu \mathrm{M}$ ) for $24 \mathrm{~h}$, uptake by microglia increased significantly in a dose-dependent manner, suggesting that LXR agonist stimulated astrocytes to secrete a product that positively regulates phagocytosis of $A \beta$ by microglia (Fig. 5A). Importantly, generation of microglia conditioned media by preexposing microglial cells for up to $24 \mathrm{~h}$ to TO901317 did not enhance $\mathrm{A} \beta$ phagocytosis (data not shown).

Generation of primary astrocytic cultures from ApoE knockout mice was performed to test whether ApoE is critical for the TO901317-mediated increase in phagocytosis of $\mathrm{A} \beta$ by microglia. Microglial cells that were exposed to conditioned media from TO901317-treated wild-type astrocytes showed normal A $\beta$ phagocytosis. In strong contrast, $\mathrm{A} \beta$ phagocytosis was nearly absent when microglial cells were exposed to conditioned media from TO901317-treated ApoE knock-out astrocytes, suggesting that astrocyte-derived ApoE is indeed a critical factor (Fig. 5B). Control experiments exposing ApoE intact or knock-out microglia to TO901317 for an identical time period ( $24 \mathrm{~h}$ ) showed that the presence or absence of ApoE in microglia did not exert any regulatory influence on subsequent $A \beta$ phagocytosis (data not shown). A further set of experiments, using astrocyte cultures generated from $\operatorname{LXR} \alpha$ knock-out, LXR $\beta$ knock-out, and LXR $\alpha / \beta$ knock-out mice, was performed to test whether the action of TO901317 depends on the presence of LXR. A $\beta$ phagocytosis was analyzed after microglial cells were exposed to conditioned media obtained from TO901317-treated wild-type, LXR $\alpha$ knock-out, LXR $\beta$ knock-out, or $\operatorname{LXR} \alpha / \beta$ knock-out astrocytes. Interestingly, $\mathrm{A} \beta$ phagocytosis was almost reduced to control levels when microglial cells were exposed to media from both LXR $\alpha$ knockout and $\operatorname{LXR} \alpha / \beta$ knock-out astrocytes, while media taken from LXR $\beta$ knock-out astrocytes did not affect the phagocytosis of $A \beta$,

fragments $6 \mathrm{E} 10$ was used. $\boldsymbol{D}$, Endogenous $A \beta$ levels remained unaffected by drug treatment as demonstrated by $E(L$ immunoassay. $E$, Representative micrographs of $A \beta$ immunohistochemistry with antibody 2964, showing the frontal cortex (CX) or subiculum (Sb) of T0901317- and vehicle-treated APP23 mice. Asterisks indicate significant differences (unpaired Student's t test, ${ }^{*} p<0.05, n=12$ ). Data represent means \pm SEM. $\boldsymbol{F}$, Thioflavin S-positive area is reduced in brain sections of APP23 mice treated with T0901317. Scale bars, $200 \mu \mathrm{m}$. WT, Wild type. 
collectively suggesting that the presence of $\mathrm{LXR} \alpha$ is a key requirement for astrocytemediated TO901317 action on microglial phagocytosis (Fig. $5 B$ ). Together, these data suggest that the stimulation of microglial $\mathrm{A} \beta$ phagocytosis by the LXR agonist TO901317 greatly depended on both astrocytic ApoE and LXR $\alpha$.

To validate these in vitro findings, immunohistochemical costaining for microglia and $A \beta$ was performed in sections from treated and untreated APP23 mice. Because of the reduced number of plaques, less activated microglia were found in TO901317treated APP23 mice generally. However, remaining small plaques in TO901317treated APP23 mice demonstrated a closer association with activated microglia compared with those in controls (Fig. 5C). The extent to which microglia were in close association with small plaques, as defined by yellow costaining of CD11b and $\mathrm{A} \beta$, was quantified and turned out to be increased by tenfold (Fig. 5C). In addition we studied the effects of short-term treatment with TO901317 in 13-month-old APP/PS1/ $\mathrm{LXR} \alpha^{+/-}$and APP/PS1/LXR $\alpha^{-/-}$mice on association of microglia with $A \beta$ in brain and lipidation of ApoE in CSF. $A \beta$ was more covered by microglia in the presence of LXR $\alpha$ and TO901317, but this was not observed in the absence of LXR $\alpha$ (Fig. 6). Lipidation of ApoE was investigated using native gel electrophoresis. Migratory velocity of ApoE in the gel depends on lipidation status. ApoE from CSF of APP/PS1/ LXR $\alpha^{-/-}$mice treated with TO901317 showed less lipidation than that of APP/PS1/ LXR $\alpha^{+/-}$mice treated with TO901317. Note that the effect of TO901317 on ApoE concentration did not depend on $\operatorname{LXR} \alpha$.

\section{Discussion}

In human $\mathrm{AD}$ brain as well as in APP transgenic mouse models, microglia respond to aggregated and misfolded $\mathrm{A} \beta$ most visible in the vicinity of $A \beta$ plaques. Experimental evidence, however, found that they are inefficient in removing fibril$\operatorname{lar} \mathrm{A} \beta$ (Bolmont et al., 2008), suggesting that either the deposition of $A \beta$ itself or secondary metabolic or inflammatory events lead to a progressive impairment of microglial clearance function. Strategies to overcome this microglial paralysis are under intense investigation and include vaccination against full-length or truncated $\mathrm{A} \beta$ peptides or stimulation of Tolllike receptor signaling (Okura et al., 2008; Scholtzova et al., 2009). Here it is demonstrated that LXR activation is able to reset microglial function, in particular, the capacity for $\mathrm{A} \beta$ phagocytosis.
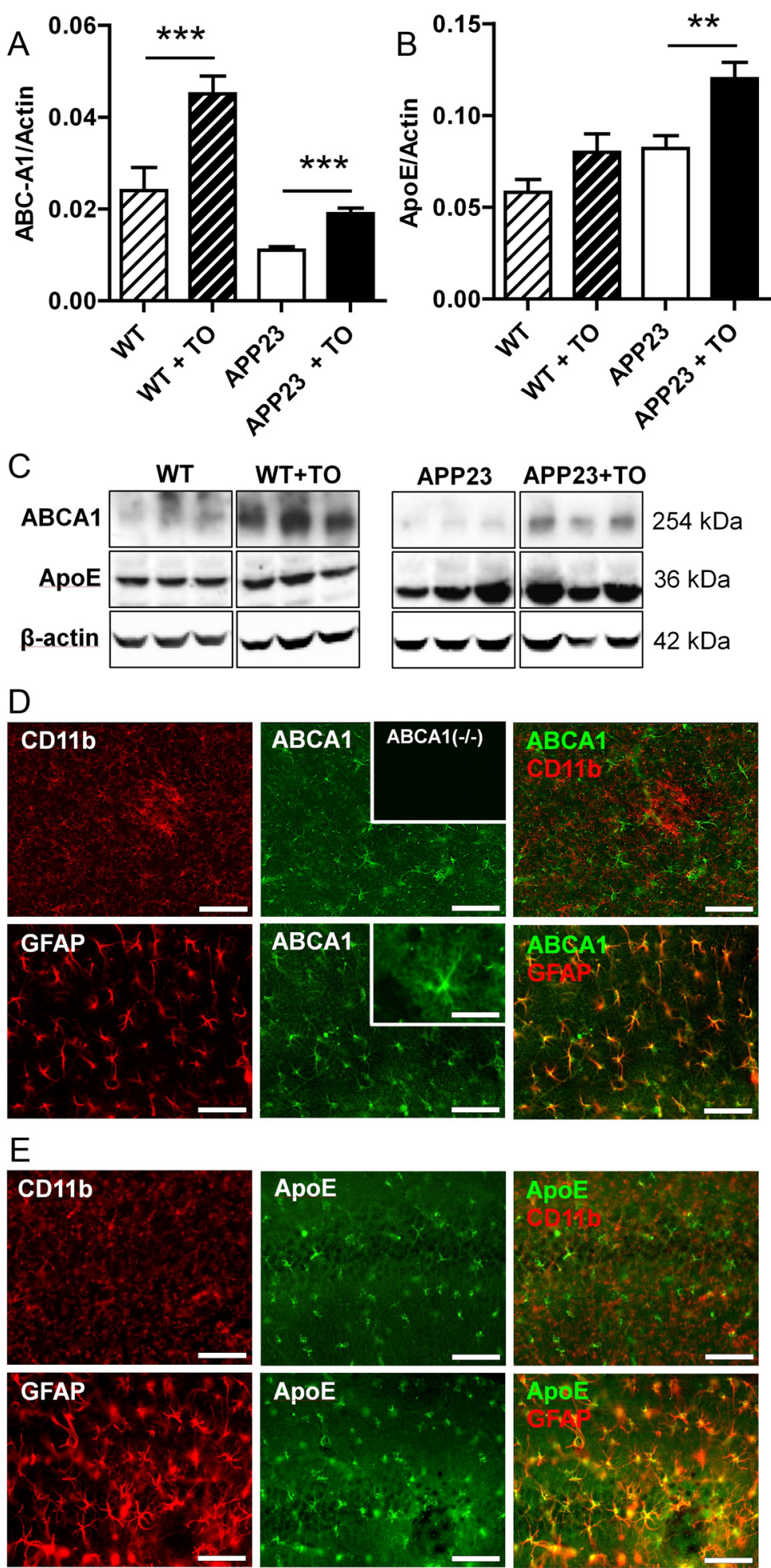

Figure 3. LXR activation positively regulates $A p o E$ and $A B C A 1$ expression in astrocytes. $A$, Densitometric quantification of Western blot detection of ApoE in brain lysates from APP23 and wild-type (WT) mice treated with either vehicle or T0901317 (T0). ApoE level was corrected for the level of the housekeeping protein actin. $\boldsymbol{B}$, Densitometric analysis of Western blot detection of $A B C A 1$ in brain lysates from APP23 and wild-type mice treated with either vehicle or T0901317. ABCA1 level was corrected for actin level. C, Representative images of ABCA1, ApoE, and $\beta$-actin Western blot detection in wild-type or APP23 mice treated with either vehicle or T0901317. D, E, Brain sections of vehicle-treated mice showing neocortex $(\boldsymbol{D})$ or hippocampus $(\boldsymbol{E})$ were immunostained for CD11b (microglial marker), GFAP (marker for astrocytic activation), and ApoE (D) or ABCA1 (E). The inset at the top of $\boldsymbol{D}$ shows absence of immunostaining in $A B C A 1$ knock-out mice, while the inset at the bottom displays the $A B C A 1$ immunostaining at higher magnification in the astrocytic arbors. Together, these immunostainings show that $\mathrm{ApoE}$ and $\mathrm{ABC} A \mathrm{1}$ expression is predominantly located in astrocytes but not in microglia in the murine brain. Asterisks indicate significant differences (ANOVA, Student's $t$ test, $\left.n=12,{ }^{* *} p<0.01,{ }^{* * *} p<0.001\right)$. Data represent means \pm SEM. Scale bars, $100 \mu \mathrm{m}$, except inset, $25 \mu \mathrm{m}$. 

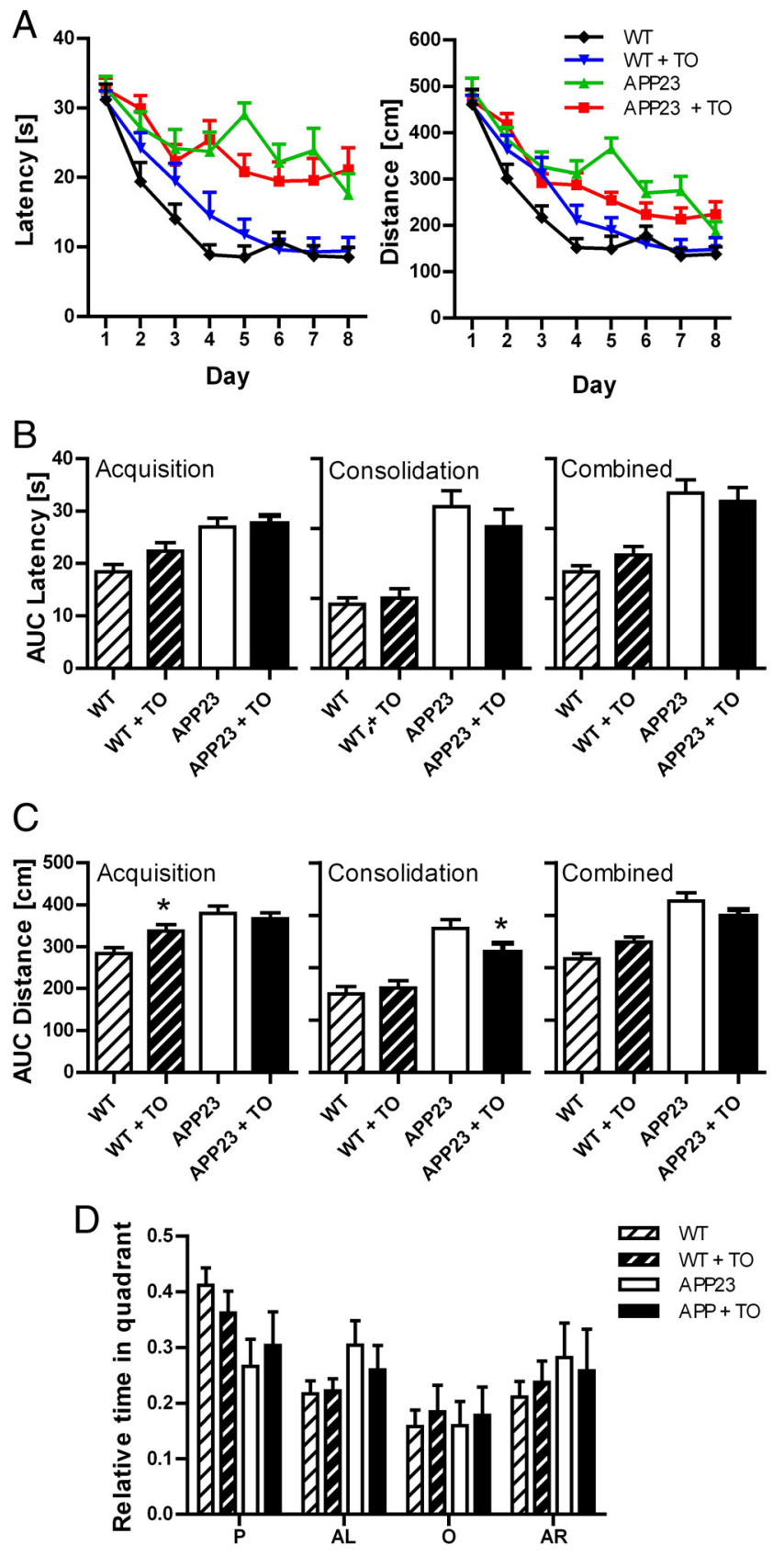

Figure 4. Spatial memory learning of APP23 mice treated with T0901317. A, Time needed to reach the hidden platform (latency in seconds) and distance traveled (in centimeters) in the Morris maze by vehicle or T0901317 (T0)-treated APP23 ( $n=16)$ and wild-type (WT) mice $(n=16) . \boldsymbol{B}, \boldsymbol{C}$, Integrated distance traveled (area under the curve) $(\boldsymbol{B})$ and time $(\boldsymbol{C})$ were determined for the whole observation period or divided in an acquisition (day 1-4) and a consolidation (day 5-8) phase. Asterisks indicate significant differences (Student's $t$ test, ${ }^{*} p<$ 0.05). D, T0901317 treatment does not reinstate place preference in the Morris water maze in APP23 mice. P, AL, 0 , and AR represent platform quadrant, and quadrant to the left, the right, and opposite of $P$, respectively. Data represent means \pm SEM. Groups consisted of 16 animals. For detailed description of the statistics, see Results.

\section{ApoE-dependent microglial phagocytosis of fibrillar A $\beta$ contributes to LXR agonist-stimulated reduction in amyloid pathology}

The central finding of the present study is the ApoE-dependent stimulation of microglial phagocytosis of fibrillar A $\beta$ by the LXR agonist TO901317 in cell culture. Either the association of fibril$\operatorname{lar} \mathrm{A} \beta$ with $\mathrm{ApoE}$ or an effect of ApoE on microglia may be responsible for the increased phagocytosis. Previously, it has been observed that the LXR agonist GW3965 stimulates degradation of soluble $\mathrm{A} \beta$ in astroglial and microglial cultures dependent on ApoE and its lipidation status (Jiang et al., 2008). These observations were proposed to explain the effect of long-term administration of GW3965 on plaque-load in Tg2576 mice. However, long-term treatment with TO901317 in 6-month-old APP23 mice did not have an effect on soluble $A \beta$ (Lefterov et al., 2007), nor did it affect endogenous soluble $A \beta$ in wild-type mice (this study). Moreover, the reduction of insoluble $\mathrm{A} \beta$ by $80 \%$ found in the present study seems to be too extensive to be caused by prevention of $A \beta$ deposition alone, based on previously reported age-dependent changes of insoluble $A \beta$ levels and disease progression in APP23 mice (Kuo et al., 2001). The hypothesis that ApoE positively regulates the phagocytosis of aggregated $A \beta$ is further supported by findings from Giunta et al. (2008), who provided evidence that aged $\mathrm{A} \beta$ phagocytosis is increased by recombinant ApoE3. More generally, but in line with our hypothesis, Grainger et al. (2004) have shown that phagocytosis of apoptotic thymocytes was reduced in ApoE-deficient macrophages, and this effect was corrected by addition of ApoE. Together, these findings lend credit to a contributory role of microglial phagocytosis of fibrillar $\mathrm{A} \beta$ in vivo following LXR activation. This hypothesis is further strengthened by the observation that activated microglial cells were closely associated with remaining plaques in the TO901317-treated APP23 mice. Next to phagocytosis, however, other mechanisms, including release of degrading proteases and peripheral clearance, may also be involved in the reduction of $\mathrm{A} \beta$ (Jiang et al., 2008).

In addition to increased phagocytosis, an altered interaction between $A p o E$ and $A \beta$, influenced by the ApoE lipidation status, might be partially responsible for the reduction of insoluble $A \beta$ in TO901317-treated mice, similar to the proposed mechanism of plaque reduction in PDAPP mice overexpressing ABCA1 (Wahrle et al., 2008). In keeping with this theory, PDAPP mice deficient for ABCA1 reveal a plaque increase at advanced age (Koldamova et al., 2005a; Wahrle et al., 2005). Long-term treatment with TO901317 resulted in increased production of ApoE and ABCA1 in aged, plaque-bearing APP23 mice, and was likely to have led to increased amounts of lipidated ApoE. It is therefore tempting to hypothesize that increased association of lipidated ApoE with $A \beta$ may have slowed down $A \beta$ aggregation and contributed to the overall $\mathrm{A} \beta$ reduction. However, a paradoxical increase in soluble $A \beta$ reported for young ABCA1overexpressing PDAPP mice (Koldamova et al., 2005a; Wahrle et al., 2008) and indicative of an altered interaction between soluble ApoE and $A \beta$, was not observed either in young APP23 mice (Lefterov et al., 2007) or in control or aged APP23 mice (this study) after long-term TO901317 treatment, together making the alternative mechanism rather unlikely. However, a role for toxic non-lipidated or poorly lipidated ApoE as a catalyst of $A \beta$ aggregation cannot be excluded entirely on the basis of the reported findings (Wahrle et al., 2005, 2008).

\section{TO901317 resets microglia for phagocytosis of $\mathrm{A} \beta$ in an} astrocyte- and LXR $\alpha$-dependent fashion

Interestingly, microglial $\mathrm{A} \beta$ phagocytosis appeared to depend on $\operatorname{LXR} \alpha$ and not LXR $\beta$, since additional knock-out of LXR $\beta$ did not reduce the effect of TO901317 any further than LXR $\alpha$ knockout only. This is in accordance with abstract data from Riddell et al. (2009) that show that only loss of LXR $\alpha$ blocked the ability of TO901317 to increase ApoE and reduce $A \beta$ levels. Other examples can be found in the literature that $\operatorname{LXR} \alpha$ and $\operatorname{LXR} \beta$ are nonredundant and can mediate differential effects when both are 

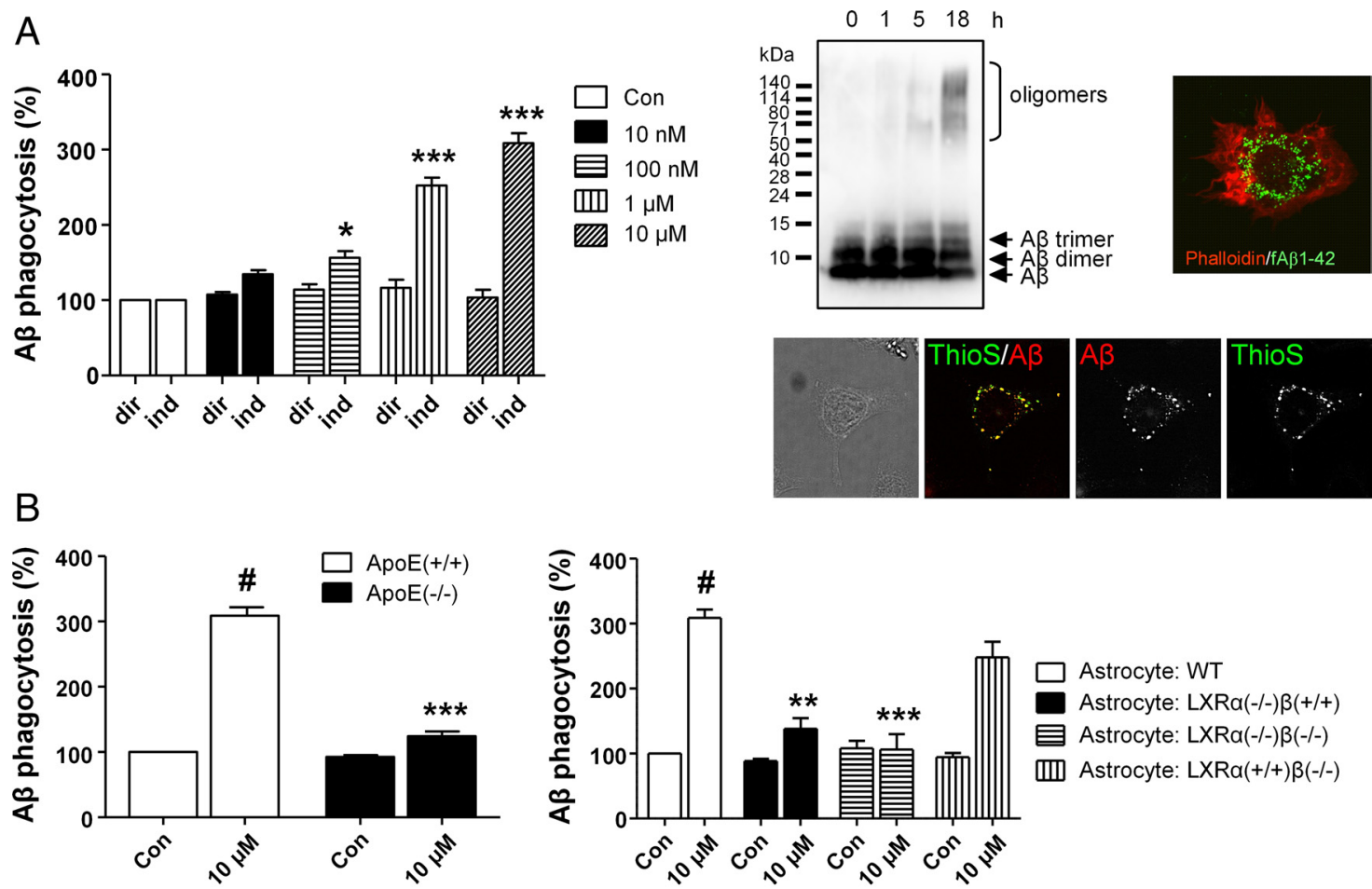

C
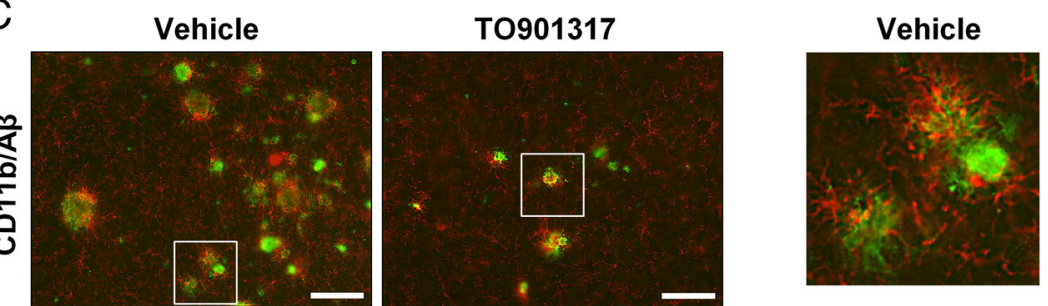

T0901317
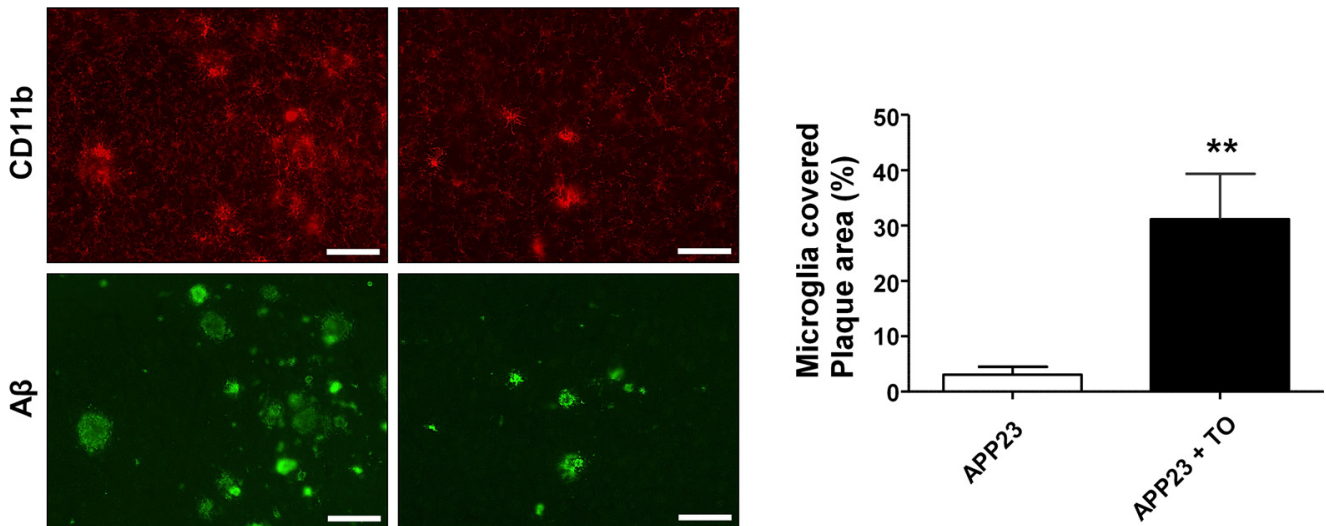

Figure 5. LXRagonist modulation of microglial $A \beta 1-42$ phagocytosis requires the presence of $L X R \alpha$ and $A p o E$ in astrocytes. $A$, Uptake of fibrillar $A \beta$ by microglial cells exposed to medium derived from either microglia (dir) or astrocytes (ind) treated with increasing concentrations of the LXR agonist T0901317. Western blot analysis demonstrated the time-dependent (from 0 to $18 \mathrm{~h}$ ) aggregation of $A \beta$ used for the described experiments. Immunocytochemical experiments, using fluorescence detection of an anti-phalloidin antibody to visualize cell boundaries (red), together with $F A M-A \beta$, were used to verify the intracellular localization of $A \beta$ within microglial cells. Thioflavin $S$ staining detecting aggregated $A \beta$ within microglia was performed. Data were analyzed by ANOVA followed by Tukey's post hoc test. Asterisks indicate significant differences from $\operatorname{dir}\left(n=5,{ }^{*} p<0.05\right.$, $\left.{ }^{* * *} p<0.001\right)$. $\boldsymbol{B}$, Analysis of microglial phagocytosis after coincubation with media derived from either $\mathrm{ApoE}^{+/+}$or Apo $\mathrm{E}^{-/-}$astrocytes exposed to $\mathrm{T} 0901317(10 \mu \mathrm{M})$ or vehicle (left), and analysis of microglial phagocytosis after coincubation with media derived from either wild-type, LXR $\alpha^{-l-} / \beta^{+/+}$, or LXR $\alpha^{-l-} / \beta^{-l-}$ astrocytes exposed to T0901317 (10 $\mu \mathrm{m}$ ) or vehicle (right). Data were analyzed by ANOVA followed by Tukey's post hoc test. Number sign (\#) indicates difference from control $(p<0.001)$. Asterisks indicate differences from stimulated wild-type $\left({ }^{* *} p<0.01,{ }^{* * *} p<0.001\right)$. C, Microglia are more associated with plaques in APP23 mice after treatment with T0901317 (TO). Amyloid plaques were stained with rabbit polyclonal 2964 and microglia with monoclonal rat anti-CD11b. Data were analyzed by unpaired Student's $t$ test $(n=$ $\left.7,{ }^{* *} p<0.01\right)$. Data represent means \pm SEM. Scale bars, $100 \mu \mathrm{m}$.

present and stimulated by LXR agonists. For instance, it has been shown that the ability of TO901317 to induce expression of ABCA1 and ABCG1 is selectively impaired in LXR $\alpha^{-1-}$ macrophages (Bischoff et al., 2010). Nonredundant roles of LXR $\alpha$ and $\operatorname{LXR} \beta$ are also in line with different studies on $\operatorname{LXR} \alpha$ and $\operatorname{LXR} \beta$ knock-out mice that have revealed that $\operatorname{LXR} \alpha$ has a more important role in cholesterol homeostasis, whereas LXR $\beta$ has functions in the immune system and neurons (Al- 
A

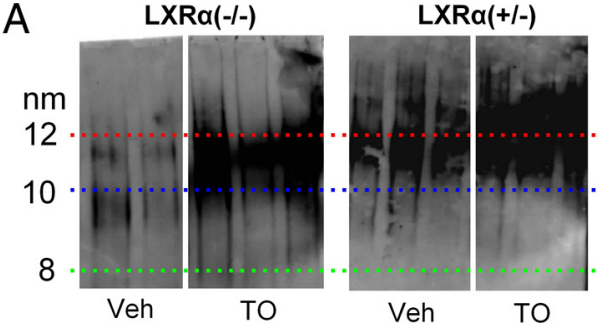

B
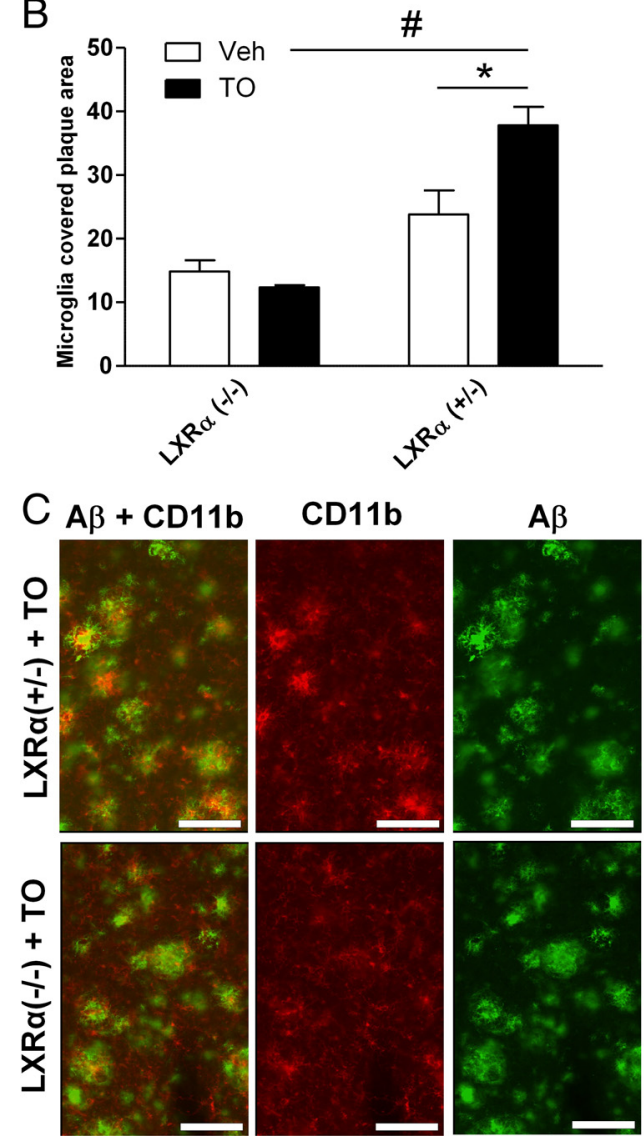

Figure 6. LXR $\alpha$ mediates ApoE lipidation and increased microglial $A \beta$ plaque association. $\boldsymbol{A}$, Native Western blot detection of ApoE in CSF derived from T0901317 (TO)- and vehicle (Veh)-treated APP/PS1/LXR $\alpha^{+/-}$and APP/PS1/LXR $\alpha^{-1-}$ mice. B, Quantitative analysis of microglial plaque association from T0901317 and vehicle-treated APP/PS1/ LXR $\alpha^{+/-}$and APP/PS1/LXR $\alpha^{-1-}$ mice. C, Representative images showing CD11bpositive microglia associated with $A \beta$-positive plaques in neocortex of T0901317-treated APP/PS1/LXR $\alpha^{+/-}$and APP/PS1/LXR $\alpha^{-/-}$mice. Data represent means \pm SEM. Data were analyzed by two-way ANOVA, followed by Student's $t$ test $\left(n=4,{ }^{*} p<0.05,{ }^{\#} p<\right.$ 0.01). Scale bars, $100 \mu \mathrm{m}$.

berti et al., 2000, 2001; Wang et al., 2002; Steffensen et al., 2004; Andersson et al., 2005; Kim et al., 2008). Moreover, even though the affinity of TO901317 for $\operatorname{LXR} \alpha$ and $\operatorname{LXR} \beta$ may not be different, the biological effects of TO901317 often indicate a greater action through $\operatorname{LXR} \alpha$ (Fiévet and Staels, 2009), whereas, at least in hepatocytes and astrocytes, the abundance of $\operatorname{LXR} \beta$ is even greater than that of $\operatorname{LXR} \alpha$ (Tobin et al., 2000; Abildayeva et al., 2006).

Colocalization of ApoE and ABCA1 supports central role of astrocytes in cholesterol metabolism and ApoE lipidation in the brain

ApoE is the primary cholesterol transporter in the brain and cholesterol is loaded onto ApoE by ABCA1. However, the reported distributions of ApoE and ABCA1 in the brain appear to mismatch. ApoE has been found in astrocytes, whereas ABCA1 has mainly been found in neurons in vivo (Koldamova et al., 2003). In the present study, it was observed that both ApoE and ABCA1 colocalized in astrocytes, matching their site of synthesis and suggesting that the levels of the respective proteins may be considerably higher in astrocytes compared with neurons and microglia. Therefore, the latter may contain some ABCA1 and ApoE, but are unlikely to provide the bulk of lipidated ApoE. Microglial ApoE synthesis has been observed in vivo under certain conditions, such as kainic acid treatment (Xu et al., 2006), but neither the presence of A $\beta$ nor TO901317 treatment appears to stimulate ApoE production by microglia in vivo (this study).

\section{Behavioral effects of TO901317 in AD models}

The present study confirmed the spatial learning impairment generally observed in APP23 mice (Van Dam et al., 2003, 2008; Buxbaum et al., 2008). Although a major effect of the compound on plaque pathology was observed, the effect on behavior was minor. The treatment was started at a stage during which APP23 mice are known to already have a considerable plaque-load and show $\mathrm{A} \beta$ plaque-associated microglia. Possibly, the impairment in neuronal function caused by $\mathrm{A} \beta$ cannot be fully reversed at this stage. $\mathrm{A} \beta$ is toxic to synapses (Koffie et al., 2009), and synaptotoxicity may have caused synaptic dysfunction or even loss in aged APP23 mice that cannot be easily restored. Future therapeutic approaches should aim, therefore, at prevention or combine reduction of pathology with restoration of neuronal circuitry.

Different studies have been performed on the effect of longterm treatment with LXR agonists on amyloid- $\beta$ and/or behavior in mice expressing mutant APP or APP and PS1. Jiang et al. (2008) found a reduction in plaque-load in 16-month-old Tg2576 mice, but tested behavior in 5-month-old Tg2576 mice. In contrast, Vanmierlo et al. (2009) did not find a reduction in plaque-load, but found a behavioral improvement in 23-monthold APPSLxPS1mut mice. In the present study, a reduction in plaque-load was observed in 13-month-old APP23 mice, but only a minor behavioral improvement. The differences between these studies are likely to be found in differences in animal models, ages, dosage of compound, type of compound, and routes and duration of administration used. For example, in the study by Lefterov et al. (2007) and in the present study, oral gavage of 50 $\mathrm{mg} / \mathrm{kg}$ TO901317 per day was used, whereas Vanmierlo et al. (2009) administered the compound in the food at a lower dose (30 mg/kg per day). Vanmierlo et al. (2009) determined the optimal dose by short-term treatment regimens. However, Lefterov et al. (2007) observed that drug effects wear off with time of treatment. Positive effects were observed with relatively simple cognitive tests, such as fear conditioning in preplaque Tg2576 mice and object recognition in plaque-bearing APPSLxPS1mut mice (Riddell et al., 2007; Jiang et al., 2008; Vanmierlo et al., 2009). In the present study, a minor drug effect was observed in the Morris water maze task, probably because this task requires more complex cognitive modalities and therefore may be more demanding.

\section{Conclusion}

In conclusion, long-term TO901317 treatment in plaque-bearing APP23 mice is able to ameliorate amyloid pathology, but only mildly improves spatial memory performance. TO901317 may affect the clearance of insoluble $\mathrm{A} \beta$, best explained by a stimulation of microglial phagocytosis of fibrillar $\mathrm{A} \beta$. This effect appears to be selectively mediated through $\operatorname{LXR} \alpha$. To fully exploit the 
potential of LXR agonists in AD models, treatment probably should be initiated at the time $\mathrm{A} \beta$ starts to deposit and be sustained into old age.

\section{References}

Abildayeva K, Jansen PJ, Hirsch-Reinshagen V, Bloks VW, Bakker AH, Ramaekers FC, de Vente J, Groen AK, Wellington CL, Kuipers F, Mulder M (2006) 24(S)-Hydroxycholesterol participates in a liver X receptor-controlled pathway in astrocytes that regulates apolipoprotein E-mediated cholesterol efflux. J Biol Chem 281:12799-12808.

Alberti S, Steffensen KR, Gustafsson JA (2000) Structural characterisation of the mouse nuclear oxysterol receptor genes LXRalpha and LXRbeta. Gene 243:93-103.

Alberti S, Schuster G, Parini P, Feltkamp D, Diczfalusy U, Rudling M, Angelin B, Björkhem I, Pettersson S, Gustafsson JA (2001) Hepatic cholesterol metabolism and resistance to dietary cholesterol in LXRbeta-deficient mice. J Clin Invest 107:565-573.

Andersson S, Gustafsson N, Warner M, Gustafsson JA (2005) Inactivation of liver X receptor beta leads to adult-onset motor neuron degeneration in male mice. Proc Natl Acad Sci U S A 102:3857-3862.

Baranowski M (2008) Biological role of liver X receptors. J Physiol Pharmacol 59:31-55.

Beaven SW, Tontonoz P (2006) Nuclear receptors in lipid metabolism: targeting the heart of dyslipidemia. Annu Rev Med 57:313-329.

Bischoff ED, Daige CL, Petrowski M, Dedman H, Pattison J, Juliano J, Li AC, Schulman IG (2010) Non-redundant roles for LXRalpha and LXRbeta in atherosclerosis susceptibility in low density lipoprotein receptor knockout mice. J Lipid Res 51:900-906.

Bolmont T, Haiss F, Eicke D, Radde R, Mathis CA, Klunk WE, Kohsaka S, Jucker M, Calhoun ME (2008) Dynamics of the microglial/amyloid interaction indicate a role in plaque maintenance. J Neurosci 28: 4283-4292.

Buxbaum JN, Ye Z, Reixach N, Friske L, Levy C, Das P, Golde T, Masliah E, Roberts AR, Bartfai T (2008) Transthyretin protects Alzheimer's mice from the behavioral and biochemical effects of A beta toxicity. Proc Natl Acad Sci U S A 105:2681-2686.

DeMattos RB, Bales KR, Parsadanian M, O’Dell MA, Foss EM, Paul SM, Holtzman DM (2002) Plaque-associated disruption of CSF and plasma amyloid-beta (A beta) equilibrium in a mouse model of Alzheimer's disease. J Neurochem 81:229-236.

Fiévet C, Staels B (2009) Liver X receptor modulators: effects on lipid metabolism and potential use in the treatment of atherosclerosis. Biochem Pharmacol 77:1316-1327.

Floden AM, Combs CK (2006) beta-amyloid stimulates murine postnatal and adult microglia cultures in a unique manner. J Neurosci 26:4644-4648.

Fujita SC, Sakura K, Tsuchiya R, Hamanaka H (1999) Apolipoprotein E is found in astrocytes but not in microglia in the normal mouse brain. Neurosci Res 35:123-133.

Giulian D, Baker TJ (1986) Characterization of ameboid microglia isolated from developing mammalian brain. J Neurosci 6:2163-2178.

Giunta B, Zhou Y, Hou H, Rrapo E, Fernandez F, Tan J (2008) HIV-1 TAT inhibits microglial phagocytosis of Abeta peptide. Int J Clin Exp Pathol 1:260-275.

Grainger DJ, Reckless J, McKilligin E (2004) Apolipoprotein E modulates clearance of apoptotic bodies in vitro and in vivo, resulting in a systemic proinflammatory state in apolipoprotein E-deficient mice. J Immunol 173:6366-6375

Heneka MT, O'Banion MK (2007) Inflammatory processes in Alzheimer's disease. J Neuroimmunol 184:69-91.

Jankowsky JL, Slunt HH, Gonzales V, Jenkins NA, Copeland NG, Borchelt DR (2004) APP processing and amyloid deposition in mice haploinsufficient for presenilin 1. Neurobiol Aging 25:885-892.

Jiang Q, Lee CY, Mandrekar S, Wilkinson B, Cramer P, Zelcer N, Mann K, Lamb B, Willson TM, Collins JL, Richardson JC, Smith JD, Comery TA, Riddell D, Holtzman DM, Tontonoz P, Landreth GE (2008) ApoE promotes the proteolytic degradation of A beta. Neuron 58:681-693.

Kim HJ, Fan X, Gabbi C, Yakimchuk K, Parini P, Warner M, Gustafsson JA (2008) Liver X receptor beta (LXRbeta): a link between beta-sitosterol and amyotrophic lateral sclerosis-Parkinson's dementia. Proc Natl Acad Sci U S A 105:2094-2099.

Kim WS, Rahmanto AS, Kamili A, Rye KA, Guillemin GJ, Gelissen IC, Jessup
W, Hill AF, Garner B (2007) Role of ABCG1 and ABCA1 in regulation of neuronal cholesterol efflux to apolipoprotein $\mathrm{E}$ discs and suppression of amyloid-beta peptide generation. J Biol Chem 282:2851-2861.

Koffie RM, Meyer-Luehmann M, Hashimoto T, Adams KW, Mielke ML, Garcia-Alloza M, Micheva KD, Smith SJ, Kim ML, Lee VM, Hyman BT, Spires-Jones TL (2009) Oligomeric amyloid beta associates with postsynaptic densities and correlates with excitatory synapse loss near senile plaques. Proc Natl Acad Sci U S A 106:4012-4017.

Koldamova RP, Lefterov IM, Ikonomovic MD, Skoko J, Lefterov PI, Isanski BA, DeKosky ST, Lazo JS (2003) 22R-Hydroxycholesterol and 9-cisretinoic acid induce ATP-binding cassette transporter A1 expression and cholesterol efflux in brain cells and decrease amyloid beta secretion. J Biol Chem 278:13244-13256.

Koldamova R, Staufenbiel M, Lefterov I (2005a) Lack of ABCA1 considerably decreases brain ApoE level and increases amyloid deposition in APP23 mice. J Biol Chem 280:43224-43235.

Koldamova RP, Lefterov IM, Staufenbiel M, Wolfe D, Huang S, Glorioso JC, Walter M, Roth MG, Lazo JS (2005b) The liver X receptor ligand T0901317 decreases amyloid beta production in vitro and in a mouse model of Alzheimer's disease. J Biol Chem 280:4079-4088.

Kuo YM, Beach TG, Sue LI, Scott S, Layne KJ, Kokjohn TA, Kalback WM, Luehrs DC, Vishnivetskaya TA, Abramowski D, Sturchler-Pierrat C, Staufenbiel M, Weller RO, Roher AE (2001) The evolution of A beta peptide burden in the APP23 transgenic mice: implications for A beta deposition in Alzheimer disease. Mol Med 7:609-618.

Lefterov I, Bookout A, Wang Z, Staufenbiel M, Mangelsdorf D, Koldamova R (2007) Expression profiling in APP23 mouse brain: inhibition of A beta amyloidosis and inflammation in response to LXR agonist treatment. Mol Neurodegener 2:20

Mulder M, Terwel D (1998) Possible link between lipid metabolism and cerebral amyloid angiopathy in Alzheimer's disease: a role for highdensity lipoproteins? Haemostasis 28:174-194.

Okura Y, Kohyama K, Park IK, Matsumoto Y (2008) Nonviral DNA vaccination augments microglial phagocytosis of beta-amyloid deposits as a major clearance pathway in an Alzheimer disease mouse model. J Neuropathol Exp Neurol 67:1063-1071.

Plump AS, Smith JD, Hayek T, Aalto-Setälä K, Walsh A, Verstuyft JG, Rubin EM, Breslow JL (1992) Severe hypercholesterolemia and atherosclerosis in apolipoprotein E-deficient mice created by homologous recombination in ES cells. Cell 71:343-353.

Riddell DR, Zhou H, Comery TA, Kouranova E, Lo CF, Warwick HK, Ring RH, Kirksey Y, Aschmies S, Xu J, Kubek K, Hirst WD, Gonzales C, Chen Y, Murphy E, Leonard S, Vasylyev D, Oganesian A, Martone RL, Pangalos MN, et al (2007) The LXR agonist TO901317 selectively lowers hippocampal Abeta 42 and improves memory in the $\mathrm{Tg} 2576$ mouse model of Alzheimer's disease. Mol Cell Neurosci 34:621-628.

Roses AD (2006) On the discovery of the genetic association of apolipoprotein E genotypes and common late-onset Alzheimer disease. J Alzheimers Dis 9:361-366.

Scholtzova H, Kascsak RJ, Bates KA, Boutajangout A, Kerr DJ, Meeker HC, Mehta PD, Spinner DS, Wisniewski T (2009) Induction of Toll-like receptor 9 signaling as a method for ameliorating Alzheimer's diseaserelated pathology. J Neurosci 29:1846-1854.

Schrader-Fischer G, Paganetti PA (1996) Effect of alkalizing agents on the processing of the beta-amyloid precursor protein. Brain Res 716:91-100.

Steffensen KR, Neo SY, Stulnig TM, Vega VB, Rahman SS, Schuster GU, Gustafsson JA, Liu ET (2004) Genome-wide expression profiling; a panel of mouse tissues discloses novel biological functions of liver $\mathrm{X}$ receptors in adrenals. J Mol Endocrinol 33:609-622.

Sturchler-Pierrat C, Abramowski D, Duke M, Wiederhold KH, Mistl C, Rothacher S, Ledermann B, Bürki K, Frey P, Paganetti PA, Waridel C, Calhoun ME, Jucker M, Probst A, Staufenbiel M, Sommer B (1997) Two amyloid precursor protein transgenic mouse models with Alzheimer disease-like pathology. Proc Natl Acad Sci U S A 94:13287-13292.

Teplow DB (2006) Preparation of amyloid beta-protein for structural and functional studies. Methods Enzymol 413:20-33.

Tobin KA, Steineger HH, Alberti S, Spydevold O, Auwerx J, Gustafsson JA, Nebb HI (2000) Cross-talk between fatty acid and cholesterol metabolism mediated by liver X receptor-alpha. Mol Endocrinol 14:741-752.

Van Dam D, D'Hooge R, Staufenbiel M, Van Ginneken C, Van Meir F, De Deyn PP (2003) Age-dependent cognitive decline in the APP23 model precedes amyloid deposition. Eur J Neurosci 17:388-396. 
Van Dam D, Coen K, De Deyn PP (2008) Cognitive evaluation of diseasemodifying efficacy of donepezil in the APP23 mouse model for Alzheimer's disease. Psychopharmacology 197:37-43.

Vanmierlo T, Rutten K, Dederen J, Bloks VW, van Vark-van der Zee LC, Kuipers F, Kiliaan A, Blokland A, Sijbrands EJ, Steinbusch H, Prickaerts J, Lutjohann D, Mulder M (2009) Liver X receptor activation restores memory in aged AD mice without reducing amyloid. Neurobiol Aging. Advance online publication. Retrieved Aug. 11, 2009. doi:10.1016/j.neurobiolaging.2009.07.005.

Vloeberghs E, Van Dam D, Franck F, Serroyen J, Geert M, Staufenbiel M, De Deyn PP (2008) Altered ingestive behavior, weight changes, and intact olfactory sense in an APP overexpression model. Behav Neurosci 122:491-497.

Wahrle SE, Jiang H, Parsadanian M, Hartman RE, Bales KR, Paul SM, Holtzman DM (2005) Deletion of Abcal increases Abeta deposition in the PDAPP transgenic mouse model of Alzheimer disease. J Biol Chem 280:43236-43242.

Wahrle SE, Jiang H, Parsadanian M, Kim J, Li A, Knoten A, Jain S, HirschReinshagen V, Wellington CL, Bales KR, Paul SM, Holtzman DM (2008) Overexpression of ABCA1 reduces amyloid deposition in the PDAPP mouse model of Alzheimer disease. J Clin Invest 118:671-682.
Wang L, Schuster GU, Hultenby K, Zhang Q, Andersson S, Gustafsson JA (2002) Liver $X$ receptors in the central nervous system: from lipid homeostasis to neuronal degeneration. Proc Natl Acad Sci U S A 99: $13878-13883$.

Whitney KD, Watson MA, Goodwin B, Galardi CM, Maglich JM, Wilson JG, Willson TM, Collins JL, Kliewer SA (2001) Liver X receptor (LXR) regulation of the LMR alpha gene in human macrophages. J Biol Chem 276:43509-43515.

Whitney KD, Watson MA, Collins JL, Benson WG, Stone TM, Numerick MJ, Tippin TK, Wilson JG, Winegar DA, Kliewer SA (2002) Regulation of cholesterol homeostasis by the liver $\mathrm{X}$ receptors in the central nervous system. Mol Endocrinol 16:1378-1385.

Xu Q, Bernardo A, Walker D, Kanegawa T, Mahley RW, Huang Y (2006) Profile and regulation of apolipoprotein E (ApoE) expression in the CNS in mice with targeting of green fluorescent protein gene to the ApoE locus. J Neurosci 26:4985-4994.

Zelcer N, Tontonoz P (2006) Liver X receptors as integrators of metabolic and inflammatory signaling. J Clin Invest 116:607-614. 